\title{
Study on the Effect of Film Therapy on the Frustration Affordability of College Students in Northeast China : based on film industry aesthetics in the age of IT
}

\author{
Du-Nan ${ }^{1}$, Yu-Chuandong ${ }^{2}$, Chee-Yong Kim ${ }^{3 *}$
}

\begin{abstract}
Considering the frustration affordability level of college entrants and investigating the frustration tolerance of undergraduates in Shenyang City University, this paper provides the basis for the research of improving frustration tolerance of undergraduates through quantitative research results and applies film therapy to the frustration regulation of college students by discussing the role of film therapy in improving frustration affordability ability of college entrants. This paper has concluded that the necessary of improving the frustration tolerance of college students in Northeast China and the feasibility of the film therapy programs on improving the frustration tolerance of college students in Northeast China. Meanwhile, this paper shows that the principle of film selection in film therapy should be based on the requirements of the aesthetics of the film industry in the IT environment. This paper provides a reference for refining the target of film therapy for film therapists to better apply film and television psychotherapy technology, and a basis for the film therapy activity program; Furthermore, it also has a certain reference significance for film and television media workers.
\end{abstract}

Key Words: Frustration Tolerance, Film Therapy, Film Industry Aesthetics in the age of IT.

\section{INTRODUCTION}

In order to meet the current needs of reforming and improve the mental health level of college students, colleges and universities should initiate to adopt various measures on cultivating qualified talents in all-round development, so as to provide a strong reserve force for the development of the country.

Since American psychologist Rosenaweig proposed frustration tolerance in 1941. He defined frustration tolerance as the ability to resist setbacks without adverse reactions, that is, the ability of the individual to adapt or resist and deal with them [1]. After this concept, some scholars began to study the word in different fields, especially the psychological frustration tolerance of college students.

In recent years, some scholars have begun to try to use film therapy to protect the frustration tolerance of college students. The flexibility, non-linguistic features, nonguidance and interaction of film therapy are coincidentally in line with the common psychological problems of college students [2]. However, there are many studies in this stage of research that have positioned the subjects on a national sample of college students. However, we reckon that the survey target should be set to a small and targeted group, so that it can provide a reference for researchers in the region to carry out a further research work and can really take effective measures to ensure talent training quality. Therefore, we target the students of this study on college students in Northeast China. With the data of the survey, the conclusions could improve and enrich examples in the field of film therapy.

Film therapy is an art therapy that emerged in the early 21 st century. Art therapy, broadly speaking, plays the role of the adjustment of human spiritual life, people will get

\footnotetext{
Manuscript received March 09, 2020; Revised May 06, 2020; Accepted May 09, 2020. (ID No. JMIS-20M-03-010)

Corresponding Author (*): Chee-Yong Kim, Department of Game Animation Engineering, Dong-eui University, 176, Eomgwang-ro, Busanjin-gu, Bus-an, 47340, Republic of Korea.

${ }^{1}$ Du-Nan, Graduate School of Storytelling, Dong-eui University, Bus-an, Republic of Korea, +82-010-9583-1966, dunan8083@naver.com.

${ }^{2}$ Yu-Chuandong, Graduate School of Design, Dong-eui University, Bus-an, Republic of Korea, +86-13046406828, 13046406828@qq.com.

${ }^{3}$ Chee-Yong Kim, Department of Game Animation Engineering, Dong-eui University, 176, Eomgwang-ro, Busanjin-gu, Bus-an, 47340, Republic of Korea.
} 
relief consciously and unconsciously in the appreciation of art, get catharsis in the artistic creation. Art therapy is a conscious and spontaneous behavior and a way to deal with stress. In a narrow sense, art therapy is a method and process of diagnose, treatment or rehabilitation of some diseases in artistic interaction with patients under the guidance of professionals [3]. Film therapy is mainly to allow patients with different diseases to watch different content, rhythm, and types of films in a completely private space to suppress and treat their etiology [4].

Film therapy has been widely used all over the world. It covers a wide range of disciplines, including art, sociology, psychology and education. In terms of academics, representative researches such as thesis A Study on the Effect of Story Content in Film Therapy of Dr.Jo Sang-ho from Dong-Eui University in South Korea have all been conducted discussions on film therapy in the field of psychology and clinical medicine [5].

Film therapy has the characteristics of flexibility, nonverbal, non-directive and interactive art therapy. Because of this feature, it has a natural fit with adult mental health counseling [6]. Film therapy uses films to communicate with the subconscious of participant .Therapists and patients can use the story plots in the films to communicate, making patients more receptive, especially when it comes to personal privacy. Program issues to lay the foundation for patient success [3]. Therefore, the application of film in psychological counseling and treatment of college students deserves further exploration and promotion. In addition, As the mental health education mechanism of many universities in China is not perfect, many universities have not established special psychological counseling centers, which is far from meeting the treatment needs of students with mental illness [7].It is unrealistic for a college student with relatively difficult financial resources to spend a lot of consultation costs in a psychotherapy clinic, therefore watching a film is a popular and economical method for college students to guide themselves. Moreover, expanding film therapy is not only a perfect match for promoting college students' mental health, but also a very urgent act in current situation.

\section{EXPERIMENTAL METHOD}

\subsection{Research Method}

A total of 146 students from Shenyang City University were selected by cluster sampling. A total of 146 questionnaires were distributed and 101 valid questionnaires were recalled. The effective rate was
$69.17 \%$. Based on the survey results, 36 participants were drawn again and randomly divided equally into two groups: experimental group and control group, with 18 members in each group. An 8 weeks group activity of film therapy was carried out on the experimental group, and the control group did not intervene for the time being. After the activities of experimental group and control group were finished, both groups were tested at the same time, and the scores of frustration affordability of college students were recorded and compared.

Table 1. General situation of 101 subjects.

\begin{tabular}{|c|c|c|c|}
\hline \multicolumn{2}{|c|}{ Variable } & Number & $\begin{array}{c}\text { Propor } \\
\text {-tion }\end{array}$ \\
\hline \multirow{2}{*}{ Gender } & Male & 38 & $37.32 \%$ \\
\cline { 2 - 4 } & Female & 63 & $62.65 \%$ \\
\hline $\begin{array}{c}\text { Only child } \\
\text { or non-only } \\
\text { child }\end{array}$ & Only child & 73 & $71.60 \%$ \\
\cline { 2 - 4 } & non-only & 28 & $27.50 \%$ \\
\hline \multirow{2}{*}{$\begin{array}{c}\text { Religious } \\
\text { beliefs }\end{array}$} & with & 29 & $28.35 \%$ \\
\cline { 2 - 4 } & without & 72 & $71.65 \%$ \\
\hline $\begin{array}{c}\text { Home } \\
\text { location }\end{array}$ & city & 67 & $65.68 \%$ \\
\cline { 2 - 4 } & rural & 34 & $34.22 \%$ \\
\hline
\end{tabular}

\subsection{Experimental subjects}

In this study, there were 38 males, accounting for $37.32 \%$ of the total number of people surveyed; 63 females, accounting for $62.65 \%$ of the total number of people surveyed; the number of only child was 73, accounting for $71.6 \%$ of the total number of people surveyed; the number of non-only child was 28 , accounting for $27.5 \%$ of the total number of people surveyed; 29 people with religious beliefs, accounting for $28.35 \%$ of the total number of people surveyed; 72 people without religious beliefs, accounting for $71.65 \%$ of the total number of people surveyed; the number of people whose families are located in cities is 67 ,accounting for $65.68 \%$ of the total number of people surveyed; the number of people whose families are located in rural areas is 34 ,accounting for $34.22 \%$ of the total number of people surveyed seeing as Table 1.

\subsection{Experimental tools}

To explore the ability of tolerate frustration in college students, the Frustration Tolerance Scale, compiled by famous Chinese psychologist Liu Ye in 2007, was adopted. In appendix, we can see the Frustration Tolerance Scale. 
Table 2. Internal Factor corresponding question.

\begin{tabular}{|c|c|c|}
\hline & $\begin{array}{l}\text { I think that finding a job after graduation } \\
\text { has a very negative impact on me. }\end{array}$ & 1 \\
\hline & $\begin{array}{l}\text { The act of deliberately pushing someone } \\
\text { else made me feel particularly angry for a } \\
\text { long time. }\end{array}$ & 2 \\
\hline & $\begin{array}{l}\text { I think the negative impact on the exam } \\
\text { from failing is very significant. }\end{array}$ & 4 \\
\hline & $\begin{array}{l}\text { When I was punished, I was nervous and } \\
\text { anxious for a long time. }\end{array}$ & 5 \\
\hline & $\begin{array}{l}\text { I think being insulted in front of people } h \\
\text { as } \\
\text { a negative impact on me. }\end{array}$ & 6 \\
\hline & $\begin{array}{l}\text { The death of a friend will make me very } \\
\text { hurt for a long time }\end{array}$ & 7 \\
\hline & $\begin{array}{l}\text { I do my best, but I still think that having } \\
\text { poor grades has a great impact on my } \\
\text { passive attitude. }\end{array}$ & 8 \\
\hline Internal & $\begin{array}{l}\text { I won't be indignant for a long time to } \\
\text { cheat others. }\end{array}$ & 9 \\
\hline & $\begin{array}{l}\text { I couldn't answer my teacher's questions in } \\
\text { class, so I still felt distressed after class. }\end{array}$ & 11 \\
\hline & $\begin{array}{l}\text { I think my parents' negativeness has almost } \\
\text { negatively affected me for a long time. }\end{array}$ & 12 \\
\hline & $\begin{array}{l}\text { When the learning burden is high, I do no } \\
\mathrm{t} \text { study for a while. }\end{array}$ & 13 \\
\hline & $\begin{array}{l}\text { I think the negative impact of others' } \\
\text { positions on me is very great. }\end{array}$ & 15 \\
\hline & $\begin{array}{l}\text { When someone points out my flaw, I try t } \\
\text { o fix it. }\end{array}$ & 16 \\
\hline & $\begin{array}{l}\text { I do my best, but I still think that having } \\
\text { poor grades has a great impact on my } \\
\text { passive attitude. }\end{array}$ & 18 \\
\hline & $\begin{array}{l}\text { After several unsuccessful attempts, I gave } \\
\text { up saying I would never try again. }\end{array}$ & 21 \\
\hline
\end{tabular}

Table 3. External Factor corresponding question.

\begin{tabular}{|l|l|l|}
\hline \multirow{7}{7}{$\begin{array}{l}\text { When I couldn't do what everyone else } \\
\text { was asking for, I avoided it and didn't d } \\
\text { o it } \\
\text { any more. }\end{array}$} & 3 \\
\hline $\begin{array}{l}\text { If I am embarrassed in front of the publi } \\
\text { c, I hurriedly leave the scene. }\end{array}$ & 10 \\
\hline $\begin{array}{l}\text { I don't study when the study load is hea } \\
\text { vy. }\end{array}$ & 14 \\
$\begin{array}{l}\text { I think that things that don't go as often } \\
\text { asyou like in life have a very negative }\end{array}$ & 17 \\
$\begin{array}{l}\text { impact on me. } \\
\text { External }\end{array}$ & $\begin{array}{l}\text { When it comes to a difficult task, I find } \\
\text { a way to overcome it. }\end{array}$ & 19 \\
\hline $\begin{array}{l}\text { After fighting a friend, I proactively } \\
\text { reconcile him. }\end{array}$ & 20 \\
\hline $\begin{array}{l}\text { When I get ridiculed by someone else, I } \\
\text { move away from those who laugh at me. }\end{array}$ & 22 \\
\hline $\begin{array}{l}\text { If I couldn't do my homework, I copied } \\
\text { it } \\
\text { from another friend. }\end{array}$ & 23 \\
\hline $\begin{array}{l}\text { When the homework is not going to be } \\
\text { done, I copy it with the work of other st } \\
\text { udents }\end{array}$ & 24 \\
$\begin{array}{l}\text { If I made a mistake and scolded my par } \\
\text { ents, I wouldn't just be at home, but aga } \\
\text { in I } \\
\text { told my parents. }\end{array}$ & 25 \\
\hline
\end{tabular}

The questionnaire uses a 5-point scoring method. Complete disagreement: 1 point; Disagreement: 2 points; Uncertainty:3 points; Agreement:4 points; Complete agreement:5 points.

There are two factors in the scale, 25 items in total. Each item lists frustration situations and possible reactions of internal thinking emotion or external behavior response and is scored at level 5. The first factor of this dimension is internal thinking emotion which involves 15 items mainly describes individuals judge the impact of frustrations on themselves and the generated emotions. The second factor is external behavior which involves 10 items mainly describes the behavior of individuals when facing frustration. The higher the score of the individual, the stronger the ability to tolerate frustration. The retest reliability of the questionnaire is 0.824 , and the empirical validity is 0.683 [2]. The topics corresponding to each factor are as follows seeing as shown in Tables 2 and 3.

\subsection{Experimental procedure}

Based on previous studies, the films selected for experimental group are from the academic field of film therapy where six films of arousing psychological coping emotion of viewers.

At the first group activity, the experimental group and the control group respectively filled out their informed consent and the team contract, after the 8th activity, they filled out the frustration affordability questionnaire and the feedback form of team activities.

The principle of the film selection is based on the viewpoint according to the Plateau in China's core journals in 2018. The selection principle of film therapy must first consider the selected films that reflect the aesthetics of the film industry under the premise of the law of the film market economy. The selected film should have inspirational narrative or the poetic expression of the author, esoteric film theme, and vague type characteristics in the IT information age [8]. The matching points of the selected films and features are as follows:

- Inspirational narrative-

The Pursuit of Happiness;

Forrest Gump

- Poetic expression of the author-Spirited Away

- Esoteric film theme

The Shawshank Redemption

The Truman Show

- Vague type characteristics-Legend Of The Demon Cat

The experiment schedule for each week is as follows seeing as in Table 4. 
After the initial screening of the scales recovered in this study, the blank or invalid questionnaires were removed for classification and compilation. SPSS software was used for data entry and statistical analysis. The statistical methods mainly included Descriptive Statistical Analysis, T Test, and One-way Analysis of Variance between Groups, etc.

\section{DATA COLLECTION AND RESULTS}

\subsection{Frustration Tolerance of College Students in Northeast China}

Frustration tolerance is divided into two factors: the internal thinking emotion factors and the external behavior performance factors.

Table 4. Experiment Schedule for Each Week.

\begin{tabular}{|c|c|c|}
\hline Week & Experimental Group & Control Group \\
\hline Week 1 & $\begin{array}{l}\text { Filled out their informed } \\
\text { consent and the team contract }\end{array}$ & $\begin{array}{l}\text { Filled out their } \\
\text { informed consent } \\
\text { And the team } \\
\text { contract }\end{array}$ \\
\hline Week 2 & $\begin{array}{l}\text { Watching film : } \\
\text { The Pursuit of Happiness }\end{array}$ & \\
\hline Week 3 & $\begin{array}{l}\text { Watching film : } \\
\text { The Shawshank Redemption }\end{array}$ & \\
\hline Week 4 & $\begin{array}{l}\text { Watching film : } \\
\text { Spirited Away }\end{array}$ & \\
\hline Week 5 & $\begin{array}{l}\text { Watching film : } \\
\text { Forrest Gump }\end{array}$ & \\
\hline Week 6 & $\begin{array}{l}\text { Watching film : } \\
\text { The Truman Show }\end{array}$ & \\
\hline Week 7 & $\begin{array}{l}\text { Watching film: } \\
\text { Legend Of The Demon Cat }\end{array}$ & \\
\hline Week 8 & $\begin{array}{l}\text { Filled out the frustration affor } \\
\text { dability questionnaire and the } \\
\text { feedback form of team } \\
\text { activities }\end{array}$ & $\begin{array}{l}\text { Filled out the } \\
\text { frustration afford } \\
\text { ability questionna } \\
\text { ire and the } \\
\text { feedback form } \\
\text { of team activities }\end{array}$ \\
\hline
\end{tabular}

Therefore, considering these two factors in the study the overall situation of frustration tolerance of college students is shown in Table 5.

According to the research results, the score of frustration tolerance of college student was $60.77 \pm$ 8.67 , the internal thinking emotion factor score was $32.80 \pm 6.81$, and the external behavior performance factor was $27.79 \pm 4.22$. According to the data from the Yearbook of the Ministry of Health of China in 2019[9], the internal thinking emotion factor was $35.8 \pm 6.90$,and the external behavior performance factor was $30.21 \pm$ 4.42.These data indicate that the frustration tolerance of college students needs to be further cultivated and strengthened, and that the frustration tolerance of college students in Northeast China is lower than that of college students nationwide. No matter from the internal thinking emotion factor or the external behavior performance factor, the score is lower than the national norm seeing as Table 6 .

Table 5. Overall situation of college students' frustration tol erance.

\begin{tabular}{|c|c|c|c|}
\hline & $\begin{array}{c}\text { Frustration } \\
\text { Tolerance }\end{array}$ & $\begin{array}{c}\text { Internal } \\
\text { Thinking } \\
\text { Emotion } \\
\text { Factor }\end{array}$ & $\begin{array}{c}\text { External } \\
\text { Behavior } \\
\text { Performance } \\
\text { Factor }\end{array}$ \\
\hline Mean & 60.77 & 32.80 & 27.97 \\
\hline SD & 8.671 & 6.809 & 4.219 \\
\hline $\mathbf{S}^{2}$ & 75.18 & 46.36 & 17.80 \\
\hline
\end{tabular}

Table 6. Comparison between Frustration Tolerance Scores of College Students in Northeast China and National Norm s.

\begin{tabular}{|l|c|c|c|c|c|}
\hline \multirow{2}{*}{ Variable } & \multicolumn{2}{|c|}{$\begin{array}{c}\text { Northeast } \\
\text { China }\end{array}$} & \multicolumn{2}{c|}{$\begin{array}{c}\text { National } \\
\text { Norm }\end{array}$} & \multirow{2}{*}{$\mathrm{t}$} \\
\cline { 2 - 5 } & $\mathrm{M}$ & $\mathrm{SD}$ & $\mathrm{M}$ & $\mathrm{SD}$ & \\
\hline Internal & 32.80 & 6.81 & 35.81 & 6.90 & $11.444^{* * *}$ \\
\hline External & 27.97 & 4.22 & 0.21 & 4.42 & $13.416^{* * *}$ \\
\hline
\end{tabular}

3.2. Differences of General Demographic Characteristics of Frustration Affordability of College Students in Northeast China 
The study of the frustration affordability of 101 college students found that the affordability of college students was generally low, and the difference between college entrants of different genders in the total score of frustration affordability was statistically significant $(\mathrm{p}=0.011)$, as shown by the total score of $40.25 \pm 5.18$ for boys in frustration affordability, which was significantly higher than the total score of $38.95 \pm 5.48$ for college entrants. The difference in the factor of external behavior of only child and non-only child was statistically significant $(\mathrm{P}=0.040)$, which showed that the college students of only child scored $40.18 \pm 5.47$ on the external performance factor, which was significantly higher than that of non-only college entrants with a score of $38.92 \pm 5$.36. The total score of college students with religious beliefs in frustration affordability was $40.17 \pm 5.25$, which was significantly higher than the score of $38.76 \pm 5.10$ for non-religious college students.

Table 7. Difference in the general demographics of the total score of frustration tolerance.

\begin{tabular}{|c|c|c|c|c|}
\hline \multicolumn{2}{|c|}{ Variable } & $\begin{array}{c}\text { Frustration } \\
\text { tolerance total } \\
\text { score }\end{array}$ & t & $p$ \\
\hline \multirow{2}{*}{ Gender } & Male & $40.25 \pm 5.175$ & 2.565 & $0.011^{*}$ \\
\cline { 2 - 5 } & Female & $38.95 \pm 5.477$ & 2.057 & $0.040^{*}$ \\
\hline $\begin{array}{c}\text { Only } \\
\text { child or } \\
\text { non-only } \\
\text { child }\end{array}$ & $\begin{array}{c}\text { Only } \\
\text { child }\end{array}$ & $40.18 \pm 5.466$ & 2.055 & $0.038^{*}$ \\
\cline { 2 - 5 } & non-only & $38.92 \pm 5.364$ & 0.173 & 0.863 \\
\hline $\begin{array}{c}\text { Religious- } \\
\text { belief }\end{array}$ & With & $40.17 \pm 5.250$ & 2.565 & $0.011^{*}$ \\
\cline { 2 - 5 } & Without & $38.76 \pm 5.100$ & 2.057 & $0.040^{*}$ \\
\hline $\begin{array}{c}\text { Home- } \\
\text { location }\end{array}$ & City & $40.19 \pm 5.100$ & 2.055 & $0.038^{*}$ \\
\cline { 2 - 5 } & Rural & $38.54 \pm 5.366$ & 0.173 & 0.863 \\
\hline
\end{tabular}

3.3. Pretest of the Scale Score Differences between Experimental Group and Control Group before Experimental Intervention
Using Paired sample T test of Variance to compare the scores of the two groups of subjects in the Undergraduate Frustration Affordability Questionnaire, there was no significant difference between the two groups, which showed that the two groups of members are comparable, intervention studies can be carried out, results from which can truly and effectively explain the causality seeing as shown in Table 8 .

Table 8. Differences in scores of the groups before experimental intervention

\begin{tabular}{|c|c|c|c|c|}
\hline & $\begin{array}{c}\text { Experimental } \\
\text { Group }\end{array}$ & $\begin{array}{c}\text { Control } \\
\text { Group }\end{array}$ & $F$ & $P$ \\
\hline $\begin{array}{c}\text { Total } \\
\text { Score }\end{array}$ & $51.33 \pm 6.095$ & $51.25 \pm 4.115$ & 0.031 & 0.970 \\
\hline Internal & $27.67 \pm 6.429$ & $26.50 \pm 3.503$ & 0.160 & 0.852 \\
\hline External & $23.67 \pm 3.172$ & $24.75 \pm 2.221$ & 0.550 & 0.582 \\
\hline
\end{tabular}

\subsection{Post-comparison of the Scale Score Differences between Experimental Group and Control Group after Experimental Intervention}

Table 9. Difference in scores of the groups after experimental intervention

\begin{tabular}{|l|c|c|c|c|}
\hline \multirow{2}{*}{$\begin{array}{l}\text { Total } \\
\text { Score }\end{array}$} & $\begin{array}{c}\text { Experimental } \\
\text { Group }\end{array}$ & $\begin{array}{c}\text { Control } \\
\text { Group }\end{array}$ & $\mathrm{F}$ & $\mathrm{P}$ \\
\cline { 2 - 5 } & $55.33 \pm 2.015$ & $51.00 \pm 3.790$ & 5.706 & $0.007^{* *}$ \\
\hline \multirow{2}{*}{ Internal } & $31.50 \pm 3.729$ & $26.17 \pm 3.298$ & 8.724 & $0.001^{* *}$ \\
\hline & & & & \\
\hline External & $23.83 \pm 2.855$ & $24.83 \pm 1.528$ & 0.475 & 0.626 \\
& & & & \\
\hline
\end{tabular}

8 weeks group activity of film therapy was carried out on the experimental group, and the control group did not intervene for the time being. After the activities of experimental group and control group were finished, both groups were tested at the same time, and the scores of frustration affordability of college students were recorded and compared. The results showed that there were significant differences in the total score of frustration affordability of college students in the experimental group and the control group after 
intervention. After further multiple comparisons, in the factor of significant difference in the scale score, the difference between the experimental group and the control group reached a significant level for details below seeing as Table 9 .

\subsection{Comparison of the Score Differences of Pretest and Post-test Intervention in Experimental Group and Control Group}

Using Paired Sample T Test to compare whether the difference between the two groups of subjects of Undergraduate Frustration Affordability Questionnaire before and after intervention was statistically significant. The experiment showed that the total score of the students in the experimental group showed higher results than the control group after the intervention seeing as the table 10 .

Table 10. The comparison of score difference between groups before and after experimental intervention.

\begin{tabular}{|c|c|c|c|c|c|}
\hline \multirow{4}{*}{ A } & & Before & After & $\mathrm{t}$ & $P$ \\
\hline & $\begin{array}{l}\text { Total } \\
\text { Score }\end{array}$ & $51.33 \pm 6.095$ & $55.33 \pm 2.015$ & 2.415 & $0.034^{*}$ \\
\hline & Internal & $27.67 \pm 6.429$ & $31.50 \pm 3.729$ & 2.192 & 0.051 \\
\hline & External & $23.67 \pm 3.172$ & $23.83 \pm 2.855$ & 0.126 & 0.902 \\
\hline \multirow{3}{*}{ B } & $\begin{array}{l}\text { Total } \\
\text { Score }\end{array}$ & $51.25 \pm 4.115$ & $51.00 \pm 3.790$ & 0.453 & 0.660 \\
\hline & Internal & $26.50 \pm 3.503$ & $26.17 \pm 3.298$ & 0.804 & 0.438 \\
\hline & External & $24.75 \pm 2.221$ & $24.83 \pm 1.528$ & 0.248 & 0.809 \\
\hline & tal & B: Control & & & \\
\hline
\end{tabular}

\section{CONCLUSION}

The frustration tolerance of college students in Northeast China generally needs to be improved, so the overall level of frustration tolerance of college students should be improved. The score is lower than that of college students in China. Boys scored higher on their internal emotions than girls, while girls scored higher on external behavior than boys.

An 8 weeks group activity of film therapy was carried out on the experimental group, and the control group did not intervene for the time being. After the activities of experimental group and control group were finished, the participants of two groups had statistical significance in the total score of the frustration affordability. Meanwhile, according to general film therapy, it has been improved on the frustration affordability of college students. Furthermore, the principle of film selection in film therapy should be based on the requirements of the aesthetics of the film industry in the IT environment as experiments have verified its effectiveness.

\section{DISCUSSION}

The results of the study show that gender differences are statistically significant in the scores of college students' ability to withstand frustration. The score of male ability to withstand frustration $(40.25 \pm 5.18)$ is significantly higher than that of female(38.95 \pm 5.48$)$, which may be related to the difference in the social roles of men and women. The society requires men to be healthy and brave from childhood, which prompted boys showed significantly higher frustration tolerance than girls. This research result is consistent with the research result of Cai Xiaoyi, a famous scholar in the field of Chinese psychology [10].

Is it an only child that statistically significant in the score of college students' ability to bear? The scores of only children among college students are significantly higher than those of non-only children. This is related to the role of the only child in the family. They are often the core of a family, so they can get more attention and protection, and they can get more support and encouragement when facing difficulties. Therefore, the only child in this study has higher frustration tolerance than the non-only child.

Religious belief is statistically significant in terms of the affordability of college students. When students with religious beliefs that encounter setbacks, religious doctrine and spirit can give them more spiritual support, which promotes the ability of people with religious beliefs in this study to withstand setbacks higher than new students without religious beliefs.

At present, the extensive application of film therapy is increasing in the field of art therapy. Based on new media, this study selects films as the media from the perspective of inheriting and carrying forward the concept of film culture content, aiming at the frustration affordability of college students, which is an exploratory study of film therapy. The results of the study show that film therapy is 
effective in improving college students' ability to withstand frustration. This is not only the film creates a natural psychological counseling scene, the viewer unconsciously invests his own consciousness in the protagonist of the film [11], but also the film as a medium of treatment helps the individual to release the hidden heart in the process of viewing the film. Stress increases the potential for self-psychological healing.

In the film therapy activities of the investigators, because of time limitation, the intervention did not follow up the study in the end, and the long-term effects of the film therapy have not been verified by practice. In future research, regular follow-up testing should be done for college students in the experimental group, and the most suitable frequency and period of film therapy should be observed through the score curve.

\section{Acknowledgement}

This work was supported by the Ministry of Education of the Republic of Korea and the National Research Foundation of Korea (NRF-2019S1A5C2A04081101).

\section{REFERENCES}

[1] Harrower, "The Stress Tolerance Test: preliminary experiments with a new projective technique utilizing both meaningful and meaningless stimuli," Journal of Personality Assess, vol.50, no.3, pp. 417-427, 1986.

[2] Liu Ye, "Research on Psychological and Social Factors of College Students' Frustration Tolerance," M.S. thesis, Nanjing Medical Univ, 2007.

[3] Sharp Conni, J. V. Smith, and A. Cole, "Cinemather apy: Metaphorically promoting therapeutic chang e," Journal of Counselling Psychology Quarterly, v ol. 15, no. 3, pp. 269-276, 2002.

[4] Dermer Shannon B., Hutchings Jennifer B., "Utilizing films in family therapy: Applications for individuals, couples, and families," The American Journal of Family T, vol. 28, no. 2, pp. 163-180, 2000.

[5] Jo Sang-ho, "A Study on the Effect of Story Content in Film Therapy," Journal of Multimedia Society, vol. 20, no. 1, pp. 93-100, 2017.

[6] Kim Ha Gang, "Effects of a Cinema Therapy-based Group Reminiscence Program on Depression and Ego Integrity of Nursing Home Elders," Journal of korean academy of psychiatric \& mental health nursing, vol. 23, no. 4, pp. 233,2014.

[7] Zhao Xiaoying, "Exploration of Work Methods for College Students' Mental Health Education," Journal of Chifeng University (Natural Science Edition), vol. 29, no. 20, pp. 151-153, 2013.

[8] Gao Yuan, 'Conflict between 'Industrial Pursuit' and 'Author Expression,," Journal of New film, vol. 04, pp. 69-76, 2018.

[9] China Ministry of Health Yearbook, Beijing: Peking Union Medical College Press,2019.

[10] Cai Xiaoyi, "On the Psychological Basis of the Concept of Spiritual Damage," Journal of Western law review, vol. 01, no. 006, pp. 70-71, 2007.

[11] Adlaf E. M., Gliksman L., and Demers A., "The prevalence of elevated psychological distress among Canadian undergraduates: findings from the 1998 Canadian CampusisepiS Survey," Journal of American College Health, vol. 50, no. 2, pp. 67-7, 2004.

\section{Authors}

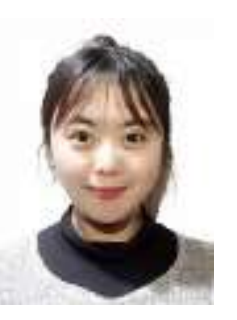

Du-Nan received her Bachelor of Arts degree, in 2010, graduated from Shenyang Conservatory of Music, China. She graduated from Liaoning University in China in 2014 with MFA. In 2016, she became a visiting fellow at Taiwan Shih Hsin University. In 2018, she entered Ph.D. in storytelling at Dong-eui University in Korea. Her main research areas are film science and visual anthropology. She in the winner of the highest award in China's microfilm industry.

In 2014-2019, she became a teacher of Shenyang City College in China, mainly teaching courses in film production.

In 2015, she was hired as the guest director of Shenyang Radio and Television of China, and in 2017 she was appointed as the executive director of China Shenyang Radio and Television Association. Since 2014, she has won the National Outstanding Instructor Award for three consecutive years. Her students have won first place in international awards such as the Davis film Festival and the Golden Rooster and Bai-hua film Festival.

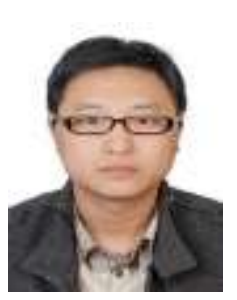

Yu-Chuandong is Doctor of Environmental Art Design, graduated from the Qing-Dao University of Technology in 2012. He is working in Yan-Tai Vocational College. His research interests include Ecological Building and Environmental Art Design

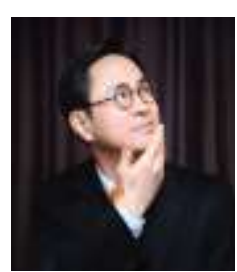

Chee-Yong Kim He received the B.S. degree, M.S. degree and Ph.D. degree from Inje University, Republic of Korea in 1991, 1994 and 2000

Respectively.

$\mathrm{He}$ is visiting professor at Oxford University in 2007, and visiting professor of the Digital Clothing Center at Seoul National University in 2012.

Currently, he is a professor of Major of Game Animation Engineering at Dong-Eui University. Prof. Kim held private exhibitions four times both in Seoul and China and joined over 230 international group exhibitions.

With his deep interest in 3D Animation, Multimedia Design, Chaos \& Fractal Design, VR / AR, Game Content Design, Virtual Fitting System and Transmedia Storytelling. 


\section{Appendix: Frustration Tolerance Questionnaire}

\section{Questionnaire}

Name:

Gender:

Whether it is an only child:

Home location:

Is there a religious belief:

Hello dear classmates! The following questionnaire can help you understand your thoughts, reactions and actions when you encounter difficulties. There is no right or wrong answer and we will keep your answers confidential, please feel free to answer. Please read each question carefully, type $\sqrt{ }$ in the appropriate option, thank you for your cooperation.

\begin{tabular}{|c|c|c|c|c|c|c|}
\hline & & $\begin{array}{l}\begin{array}{l}\text { Complete } \\
\text { disagreement }\end{array} \\
\end{array}$ & disagree & uncertainty & agree & $\begin{array}{l}\text { complete } \\
\text { agreement }\end{array}$ \\
\hline 1 & $\begin{array}{l}\text { I think that finding a job after graduation has a very } \\
\text { negative impact on me. }\end{array}$ & & & & & \\
\hline 2 & $\begin{array}{l}\text { The act of deliberately pushing someone else made me } \\
\text { feel particularly angry for a long time. }\end{array}$ & & & & & \\
\hline 3 & $\begin{array}{l}\text { When I couldn't do what everyone else was asking for, I } \\
\text { avoided it and didn't do it any more. }\end{array}$ & & & & & \\
\hline 4 & $\begin{array}{l}\text { I think the negative impact on the exam from failing is } \\
\text { very significant. }\end{array}$ & & & & & \\
\hline 5 & $\begin{array}{l}\text { When I was punished, I was nervous and anxious for a } \\
\text { long time. }\end{array}$ & & & & & \\
\hline 6 & $\begin{array}{l}\text { I think being insulted in front of people has a negative } \\
\text { impact on me. }\end{array}$ & & & & & \\
\hline 7 & $\begin{array}{l}\text { The death of a friend will make me very hurt for a long } \\
\text { time }\end{array}$ & & & & & \\
\hline 8 & $\begin{array}{l}\text { I do my best, but I still think that having poor grades has a great } \\
\text { impact on my passive attitude. }\end{array}$ & & & & & \\
\hline 9 & I won't be indignant for a long time to cheat others. & & & & & \\
\hline 10 & $\begin{array}{l}\text { If I am embarrassed in front of the public, I hurriedly } \\
\text { leave the scene. }\end{array}$ & & & & & \\
\hline 11 & $\begin{array}{l}\text { I couldn't answer my teacher's questions in class, so I still felt } \\
\text { distressed after class. }\end{array}$ & & & & & \\
\hline 12 & $\begin{array}{l}\text { I think my parents' negativeness has almost negatively } \\
\text { affected me for a long time. }\end{array}$ & & & & & \\
\hline 13 & $\begin{array}{l}\text { When the learning burden is high, I do not study for a } \\
\text { while. }\end{array}$ & & & & & \\
\hline 14 & I don't study when the study load is heavy. & & & & & \\
\hline 15 & $\begin{array}{l}\text { I think the negative impact of others' positions on has a } \\
\text { very negative impact on me. }\end{array}$ & & & & & \\
\hline 16 & When someone points out my flaw, I try to fix it. & & & & & \\
\hline 17 & $\begin{array}{l}\text { I think that things that don't go as often as you like in } \\
\text { life }\end{array}$ & & & & & \\
\hline 18 & $\begin{array}{l}\text { I do my best, but I still think that having poor grades has a great } \\
\text { impact on my passive attitude. }\end{array}$ & & & & & \\
\hline 19 & $\begin{array}{l}\text { When it comes to a difficult task, I find a way to } \\
\text { overcome it. }\end{array}$ & & & & & \\
\hline 20 & After fighting a friend, I proactively reconcile him. & & & & & \\
\hline 21 & $\begin{array}{l}\text { After several unsuccessful attempts, I gave up saying I } \\
\text { would never try again. }\end{array}$ & & & & & \\
\hline 22 & $\begin{array}{l}\text { When I get ridiculed by someone else, I move away from those } \\
\text { who laugh at me. }\end{array}$ & & & & & \\
\hline 23 & $\begin{array}{l}\text { If I couldn't do my homework, I copied it from another } \\
\text { friend. }\end{array}$ & & & & & \\
\hline 24 & $\begin{array}{l}\text { When the homework is not going to be done, I copy it with the w } \\
\text { ork of other students }\end{array}$ & & & & & \\
\hline 25 & $\begin{array}{l}\text { If I made a mistake and scolded my parents, I wouldn't } \\
\text { just beat home, but again I told my parents. }\end{array}$ & & & & & \\
\hline
\end{tabular}

